\title{
Src activation by cGMP/PKG II in osteoblasts: characterization of a mechano-sensitive signalling complex
}

\author{
Hema Rangaswami ${ }^{1}$, Raphaela Schwappacher ${ }^{1}$, Nisha Marathe ${ }^{1}$, Darren E Casteel ${ }^{1}$, Bodo Haas², Alexander Pfeifer ${ }^{2}$, \\ Sanford Shattil', Gerry Boss', Renate B Pilz ${ }^{1 *}$ \\ From 5th International Conference on cGMP: Generators, Effectors and Therapeutic Implications \\ Halle, Germany. 24-26 June 2011
}

\section{Background}

Mechanical stimulation of bone cells is critical for maintaining bone mass and strength, and a better understanding of how mechanical stimuli are converted into intracellular signals to activate an anabolic program in osteoblasts/cytes is fundamental to improving treatments for osteo-degenerative diseases [1,2]. Weight bearing and locomotion stimulate interstitial fluid flow through the bone canalicular system, and the resultant shear stress is thought to be a major mechanism whereby mechanical forces stimulate osteoblast/osteocyte growth and differentiation $[1,2]$. In primary osteoblasts and osteoblast/ cyte-like cell lines, fluid shear stress induces rapid expression of $c$-fos, fra-1, fra-2, and fosB/ $f$ fosB mRNAs [3]; these genes encode transcriptional regulators important for osteoblast proliferation and differentiation, as demonstrated by the phenotypes of mice that over-express or lack these proteins, respectively [4]. We have previously shown that fluid shear stress increases osteoblast/cyte nitric oxide (NO) production, leading to increased cGMP synthesis and activation of cGMP-dependent protein kinases (PKGs). The NO/cGMP/PKG signaling pathway is required for shear-induced expression of all four fos family genes, and induction of these genes is mediated through activation of the mitogen-activated protein kinases Erk1/2 [3]. However, molecular mechanisms leading to Erk activation in shear-stressed osteoblasts are largely unknown.

\footnotetext{
*Correspondence: rpilz@ucsd.edu

'Department of Medicine, University of California at San Diego, La Jolla, CA 92093, USA

Full list of author information is available at the end of the article
}

\section{Results}

We have now defined the events leading from shear stress activation of NO/cGMP/PKG II to the activation of Src [5]; we show that this pathway is required for Erk activation, and controls osteoblast proliferation and survival. We found a novel link between NO/cGMP/PKG and $\beta 3$ integrins, the key mechano-sensors in bone, and show that PKG II activates $\beta 3$-associated Src by activating the tyrosine phosphatase Shp-1. PKG II directly phosphorylates and stimulates Shp-1 activity, which de-phosphorylates a C-terminal, inhibitory phosphorylation site on Src, leading to Src activation. Fluid shear stress triggers PKG II, Src, and Shp-1/2 recruitment to a mechano-sensitive complex containing $\beta 3$ integrins, defining a novel "mechanosome". We found that PKG II-null mice have defective osteoblast Src/Erk signaling, decreased Erk-dependent gene expression in bone, and impaired osteoblast-dependent, membranous bone formation. These results complement previous studies in PKG II-deficient mice, which showed defective chondroblast differentiation and endochondral bone formation, and studies in NO synthase-deficient mice, which demonstrated an important role of NO in osteoblast biology [6,7].

\section{Conclusion}

Our findings reveal crosstalk between NO/cGMP/PKG and integrins, establish a new mechanism of Src activation, and fill a gap in our understanding of how mechanical forces acting on cell-matrix adhesions are translated into cellular responses. Since Src controls Erk, a key regulator of osteoblast growth and survival, our results support using PKG-activating drugs as mechano-mimetics for treating osteoporosis. 


\section{Author details}

'Department of Medicine, University of California at San Diego, La Jolla, CA 92093, USA. ${ }^{2}$ Institute for Pharmacology and Biomedical Center, University of Bonn, 53105 Bonn, Germany.

Published: 1 August 2011

\section{References}

1. Ehrlich PJ, Lanyon LE: Mechanical strain and bone cell function: a review. Osteoporos. Int 2002, 13:688-700.

2. Ozcivici E, Luu YK, Adler B, Qin YX, Rubin J, Judex S, Rubin CT: Mechanical signals as anabolic agents in bone. Nat Rev Rheumatol 2010, 6:50-59.

3. Rangaswami H, Marathe N, Zhuang S, Chen Y, Yeh JC, Frangos JA, Boss GR, Pilz RB: Type II cGMP-dependent protein kinase mediates osteoblast mechanotransduction. J Biol Chem 2009, 284:14796-14808.

4. Wagner EF, Eferl R: Fos/AP-1 proteins in bone and the immune system. Immunol Rev 2005, 208:126-140.

5. Rangaswami H, Schwappacher R, Marathe N, Zhuang S, Casteel DE, Haas B, Chen Y, Pfeifer A, Kato H, Shattil S, Boss GB, Pilz RB: Cyclic GMP and protein kinase $\mathrm{G}$ control a Src-containing mechanosome in osteoblasts. Sci Signal 2010, 3:ra91.

6. Pfeifer A, Aszòdi A, Seidler U, Ruth P, Hofmann F, Fässler R: Intestinal secretory defects and dwarfism in mice lacking cGMP-dependent protein kinase II. Science 1996, 274:2082-2086.

7. Armour KE, Armour KJ, Gallagher ME, Godecke A, Helfrich MH, Reid DM, Ralston SH: Defective bone formation and anabolic response to exogenous estrogen in mice with targeted disruption of endothelial nitric oxide synthase. Endocrinology 2001, 142:760-766.

doi:10.1186/1471-2210-11-S1-024

Cite this article as: Rangaswami et al: Src activation by cGMP/PKG II in osteoblasts: characterization of a mechano-sensitive signalling complex. BMC Pharmacology 2011 11(Suppl 1):O24.

\section{Submit your next manuscript to BioMed Central and take full advantage of:}

- Convenient online submission

- Thorough peer review

- No space constraints or color figure charges

- Immediate publication on acceptance

- Inclusion in PubMed, CAS, Scopus and Google Scholar

- Research which is freely available for redistribution

Submit your manuscript at www.biomedcentral.com/submit 